| GOSOS | Gaziosmanpaşa Üniversitesi Sosyal Bilimler Araştırmaları Dergisi Gaziosmanpasa University Social Sciences Researches Journal

(Kış 2016) 11/2: 1-23 / (Winter 2016) 11/2: 1-23

Makale Geliş Tarihi:08.06.2016. Yayın Kabul Tarihi:14.11.2016.

Doi Number :http://dx.doi.org/10.19129/sbad.296

\title{
RUM EYALETİ EVLATLIK VAKIFLARINDAN BİR ÖRNEK: ABDÜLVEHHAB OĞULLARI EVLATLIK VAKFI
}

Ali AÇIKEL*

Osmanlı öncesi devirlerde Orta Anadolu ve Doğu Anadolu'da mevcut olan malikâne uygulaması, bu bölgelerin Osmanlı idaresine girmesiyle bir tür çifte vergilemeyi ifade eden malikâne-divânî sistemine dönüşmüştür. Bu yeni sistemde reaya iki öşür ödedi: bir öşür malikâne hissesi olarak malikâne sahibine, bir ikinci öşür divânî hissesi olarak tımar sistemi çerçevesinde devletin tayin ettiği görevliye. Malikâne hissesini tasarruf edenler, gelirlerinin tamamını ya da bir kısmını zamanla evlatlık vakfa dönüştürmüşlerdir. Bu şekilde Anadolu'da çok sayıda evlatlık vakıf ortaya çıkmıştır.

Osmanlı döneminde malikâne-divânî sisteminin uygulandı̆̆ı eyaletlerden birisi de

Öz Rum eyaletidir. Bu eyalette de malikâne sahipleri gelirlerinin tamamını ya da bir kısmını zamanla evlatlık vakfa dönüştürmüşlerdir. Rum eyaletinde kurulan evlatlık vakıflar arasında gelirleri bakımdan en büyüklerinden birisi Abdülvehhab oğulları evlatlık vakfıdır. Abdülvehhab ve oğulları malikâne gelirlerinin önemli bir kısmını evlatlık vakfa aktarırken çok az bir kısmını ise mülk olarak tasarruf etmişlerdir.

Bu makalede arşiv kaynakları yardımı ile Abdülvehhab'ın kimliği, evlatlık vakfı ile malikâne mülkleri incelenmiştir. Çalışma, Osmanlı döneminde Abdülvehhab'ın evlatlık vakfı ve malikâne mülklerinin durumunu ortaya kayarak Rum eyaletinin sosyal tarihine katkı sunmayı amaçlamaktadır.

Anahtar Kelimeler: Rum eyaleti, evlatlık vakıf, malikâne, Abdülvehhab, malikânedivânî sistem.

\section{AN EXAMPLE OF THE WAKFS FOR OFF-SPRINGS OF THE PROVINCE OF RUM:} THE WAKF FOR OFF-SPRING OF ABDULVEHHAB

\begin{abstract}
The malikane regime which existed in central and eastern Anatolia during the preOttoman periods was transformed into the malikane-divani system which means a kind of double taxation with the entering of this regions under the Ottoman administration. Under this system, tax-paying subjects paid double tithe, one tithe to the local nobles who had already held the ownership right to the land as malikâne part, a second tithe to a dirlik-holding official assigned by the State in the context of the tımar system as divani part. The malikane holders gradually transformed some part or the whole of their revenues into wakfs for their offsprings. In this way, a number of wakfs for off-springs were established in Anatolia.

One of the provinces that the malikane-divani system was applied during the
\end{abstract}

Abstract

\footnotetext{
* Prof. Dr., Gaziosmanpaşa Üniversitesi Fen Edebiyat Fakültesi Tarih Bölümü Öğretim Üyesi. E. mail: ali.acikel@gop.edu.tr; ali.acikel66@yahoo.com.
} 


\title{
Ali AÇIKEL
}

\begin{abstract}
Ottoman period was also the province of Rum. In this province, the malikane holders also gradually transformed some part or the whole of their revenues into waqfs for their off-springs. One of the greatest ones in terms of revenues among the waqfs for off-springs founded in the province of Rum was the waqf for offspring of Abdulvahhab. Abdulvahhab and his sons allotted the important part of their malikane revenues to their waqf of off-spring while they used the minor part of their malikane revenues as personal asset.

In this article, the identification of Abdulvahhab, his waqf of off-spring and malikane holdings were examined with the help of the archival documents. Examining the situation of the waqf for off-spring and malikane holdings of Abdulvehhab during the Ottoman period, the study aims to contribute to the social history of the province of Rum.
\end{abstract}

Key Words: the province of Rum, vaqf for off-spring, revenue belonging to the landlord, Abdulvahhab, malikâne-divânî system.

\section{GİRIŞ}

Vakıf Arapça bir kelime olup “durdurmak", "alıkoymak", "durma", "durdurma" manalarına gelmektedir. Kelimenin çoğulu "evkâf" tır. Terim anlamı bir mal veya mülkün sevap kazanmak amacıyla doğrudan ve dolaylı bir şekilde toplumun yararına tahsis edilmesidir1. Bu tahsis dinî, sosyal ve iktisadi eserler yaptırmak ve bunların ihtiyaçları için yeterli miktarda gelirler bağlamak şeklinde olabileceği gibi çok daha farklı alanlarda da olabilmektedir. Taşınır (menkul) veya taşınmaz (gayrimenkul) mallarını toplumun yararına tahsis edenlere vâkıf adı verilmektedir.

Vakıflar genel olarak mahiyet bakımından hayrî ve zürrî vakıflar olmak üzere iki kısımda incelenebilir². Hayrî vakıflar sevap ve ibadet kabilinden bir fiil işlemek kasdıyla doğrudan bütün insanlara veya sadece fakirlere yardım için kurulan

\footnotetext{
${ }^{1}$ Vakfın çeşitli şekillerdeki tanımları için bkz. Şemseddin Sami, Kâmûsı ı Türk̂̀, Desa'adet 1317, s. 1495-6; Bahaeddin Yediyıldız, "Vakıf", İA, C. 13, İstanbul 1986, s. 153; Aynı yazar, XVIII. Yüzyllda Türkiye'de Vakıf Müessesesi Bir Sosyal Tarih İncelemesi, Ankara 2003, s. 8-10; Midhat Sertoğlu, Osmanl Tarih Lügati, İstanbul 1986, s. 105; Ahmet Akgündüz, İslam Hukukunda ve Osmanlı Tatbikatında Vakıf Müessesesi, Ankara 1996, s. 76-94.

2 Akgündüz, a.g.e., s. 270. Nazif Öztürk vakıfları mahiyet itibariyle dört başlık altında (ayni ile intifa olunan hayri vakıflar, geliri ile intifa olunan akar vakıfları, zürri=evlatlık vakıflar ve avarız vakıfları) tasnif etmiştir (bkz. Nazif Öztürk, Menşe'i ve Tarihi Gelişimi Açısından Vakıflar, Ankara 1983, s. 82-87).
} 


\section{Rum Eyaleti Evlatlık Vakıflarından Bir Örnek: Abdülvehhab Oğulları Evlatlık Vakfı}

vakıflardır. Bu tür vakıflarda vakıftan yararlananlar arasında vâkıfın fakir akrabaları da bulunabilir ${ }^{3}$. Toplumun tamamı veya sinırlı bir kesiminin yararlandığ 1 cami, okul, kütüphane, hastane ve aşevi gibi hayır kurumu vakıfları ile bu kurumlara akar sağlayan nakit para, emlak, işhanı, çarşı ve ev gibi menkul ve gayrimenkuller hayrî vakıflar kapsamindadır"

Zürrî ya da evlatlık vakıflar vakfedenin zürrîyetinden yani evlatlarından olanların faydalanmaları için kurulan vakıflardır ${ }^{5}$. Bu tür vakıflarda vakfedilen malın gelirinin tamamı veya tamamına yakını vâkıfın evlat ve torunlarına tahsis edildiğinden hayır şartı ya sembolik ya da neslin yok olması halinde söz konusudur'6. Hayır şartının sınırlılığı ve bazı mirasçıların mirastan mahrum edilmesi, tarih boyunca evlatlık vakıfların İslam hukuku açısından caizliğinin tartışılmasına neden olmuştur. 19. yüzyılda Mısır ulemasının zürrî vakıfların İslam miras hukukuna aykırı olduğu yönünde görüş bildirmesi üzerine bu tür vakıfların kaldırılması gündeme gelmiş, daha sonra belli sınırlamalarla oluşturulmasına izin verilmiştir7. Mısır' daki bu fikirlerden ve bazı oryantalistlerin vakıf karşıtı düşüncelerinden etkilenen Ömer Lütfi Barkan, Osmanlı Devleti'nde zürrî vakıfların kuruluş amaçları hakkında bazı olumsuz kanaatler ortaya koymuştur. O'na göre, Osmanlı Devleti'nde zürrî vakıflar sistemi, gerek devletin müsadere temayüllerine ve gerekse İslam miras hukukunun dağıtıcı tesirlerine karşı ortaya çıkmıştır. Zürrî vakıflar çoğunlukla mülkün nesiller elinde bütünlüğünü muhafaza ederek ailenin şeref ve varlığını idame ettirmek amacıyla tesis edilmiştir. Bir aile namına vakfedilmiş olan bir mülke, vakıf olması sebebiyle vâkıfın mirasçıları tarafından müdahale edilemez. Ayrıca vakıf haline getirilen mülkün borç için veya diyet olarak haczi ve çeşitli maksatlar için tahsisi de mümkün değildir. Evlatlık vakıf mülkler, vâkıfın tayin edeceği şartlar içinde, nesiller elinde bütün olarak kalabilecektir8.

\footnotetext{
${ }^{3}$ Akgündüz, a.g.e., s. 270.

4 Öztürk, a.g.e., s. 82-83.

${ }_{5}^{5}$ Ali Himmet Berki, Vakfa Dair Yazılan Eserlerle Vakfiye ve Benzeri Vesikalarda Geçen Istılah ve Tâbirler, Ankara 1966, s. 17.

6 Öztürk, a.g.e., s. 84.

7 Akgündüz, a.g.e., s. 271-2.

8 Ömer Lütfi Barkan, “Türk-İslam Toprak Hukuku Tatbikatının Osmanlı İmparatorluğu'nda Aldığı Şekiller Şer'i Miras Hukuku ve Evlatlık Vakıflar", Türkiye'de Toprak Meselesi Toplu Eserler 1, İstanbul 1980, s. 212-214.
}

| Gaziosmanpaşa Üniversitesi Sosyal Bilimler Araştırmaları Dergisi 


\section{Ali AÇIKEL}

Barkan'ın ve Mısır ulemasının aksine, İslam hukukçularının büyük çoğunluğu ise mirasçılara yapılan vakıfları yani zürrî vakıfları caiz görmüşlerdir. Onlara göre, evlatlık vakıf kurmak miras kaidelerine savaş açmak manası taşımaz. Zira insan, vakıf yoluyla değil bağış yoluyla da istediğini yapabilmektedir. Vakfı tercih etmesi, insanın hayır kasdını göstermektedir. Hz. Peygamber'in "fakire sadaka sadakadır; yakın akrabaya sadaka ise hem sadaka hem sıladır" hadis-i şerifi, akraba için yapılan vakfın sadaka olduğuna işaret etmektedir. Bu hadis-i şeriften hareketle birçok sahabe yakın akrabasına vakıflar tesis etmiştir 9 . Ancak her şeyde olduğu gibi vakıf tesisinde de suiistimal yaşanmıştır. Osmanlı döneminde zürrî vakıfları kabul etmeyenlerin iddialarını tasdik eden vakfiyeler de vardır. Burada evlatlık vakfın caiz olmasında temel kıstas vâkıfın amaç ve maksadıdır. Eğer vâkıf, yaptığı zürrî vakıflarla, yakın akrabalarının ihtiyaçlarını temin etmeyi amaçlıyor ve neticede vakfı fakirlere tahsis ediyorsa, bu tür vakıflar geçerlidir. Ancak vâkıfın amacı, bazı mirasçılarını mirastan mahrum etmek ve yaptığı vakıfla İslam miras hukukunun tesirini ortadan kaldırmak ise, bu çeşit vakıflar zaten caiz olmayacaktır ${ }^{10}$.

$\mathrm{Bu}$ makalede Osmanlıların ilk devirlerinde Rum eyaletinde kurulan Abdülvehhab oğulları evlatlık vakfı incelenmiştir.

\section{2- Abdülvehhab'in Kimliği}

Abdülvehhab'ın mülklerine ve evlatlık vakfının gelir elde ettiği yerleşim yerlerine bakıldığında bunların Sivas veya Rum eyaletinin muhtelif bölgelerinde olduğu görülmektedir. Rum eyaleti Osmanlıların fethi sırasında bir yerel aristokrasi ile karşılaştıkları Kuzey Orta Anadolu'nun büyük bölümünü oluşturmaktaydı. Yerel aristokrasinin kökenleri ise 13. ve 14. yüzyıllarda Anadolu Selçukları ve onların halefi olan küçük beyliklere dayanmaktaydı. Selçuklu sultanları ve küçük beyliklerin idarecileri yerel beylere çok sayıda kırsal yerleşim yerinin vergi toplama haklarını bahşetmişlerdi. 1393-1398 yılları arasında Osmanlılar Rum eyaleti topraklarını ilhak ettiklerinde yerel beylerin vergi toplama haklarını ve imtiyazlarını kabul ederek bölgede farklı bir toprak idaresi ve vergileme sistemi uygulamaya başladılar. Bu, bir vergi birimi (köy veya mezra) gelirinin divânî hisse ve malikâne hisse olarak paylaşıldığı

${ }^{9}$ Akgündüz, a.g.e., s. 271-2.

${ }^{10}$ Akgündüz, a.g.e., s. 273.

Gaziosmanpasa University Social Sciences Researches Journal 


\section{Rum Eyaleti Evlatlık Vakıflarından Bir Örnek: Abdülvehhab Oğulları Evlatlık Vakf1}

"malikâne-divânî sistemi" idi. Divanî hisse tımar sahiplerine, malikâne hisse ise mülk sahibi yerel beylere tahsis edilmişti. Başka bir ifade ile bu sistem altında köylüler iki öşür ödediler: bir öşür divan̂̂ hisse olarak, diğer örfi vergilerle birlikte, tımar sistemi çerçevesinde tımarlı sipahiye veya sancak idarecisine; bir ikinci öşür malikâne hissesi olarak yerel beylere veya onların kurdukları vakıflara ${ }^{11}$. Bazı durumlarda divanî ve mâlikâne hisseleri ya tımar sahiplerine, ya üst düzey sancak idarecilerine ya da bölge içinde veya dışındaki vakıflara birlikte tahsis edildi. Mufassal tahrir defterlerinde bu husus "iki baştan" şeklinde belirtilmiştir.

Osmanlılar döneminde malikâne-divânî sistemin uygulandığı Rum eyaletinde ve diğer eyaletlerde malikâne sahiplerinin tarihi kimlikleri hakkında yeterli bilgi bulunmamaktadır. Bunlar kimlerdi? Osmanlılar zamanında reayanın ödediği vergiler üzerinden malikâne hissesi almaya neden hak kazandılar? Malikâne-divânî sistemi üzerine günümüze kadar bir hayli çalışma yapılmasına rağmen, malikâne sahiplerinin tarihi kimlikleri ve onların malikâne hisselerini nasıl almaya hak kazandıkları üzerine henüz tatminkâr cevaplar bulunamamıştır. Bu durum ya aile arşivlerinin olmaması ya da yerel ölçekte zengin bilgiler içeren kadı sicillerinin günümüze ulaşmamış olmasından kaynaklanmaktadır. Bu iki önemli kaynağın eksikliğinde geriye aynı

11 Mâlikâne-divânî sistem ve malikâne hisse sahipleri hakkında birçok çalışma yapılmıştır. Birkaç örnek için bkz. Ömer Lütfi Barkan, “Türk-İslam Hukuku Tatbikatının Osmanlı İmparatorluğu'nda Aldığı Şekiller: Mâlikâne-Divânî Sistemi", Türk Hukuk ve İktisat Tarihi Mecmuası, cilt: 2, İstanbul 1939, s. 119-184 (Aynı yayının yeniden basımı için ayrıca bkz. Ömer Lütfi Barkan, Türkiye'de Toprak Meselesi, Toplu Eserler, I, Gözlem Yayınları, İstanbul 1980, s. 151208); Irène Beldicaeanu-Steinherr, "Fiscalité et Formes de Possession de la Terre Arable dans L'Anatolie Préottomane", JESHO (1976), XIX, s. 233-322; Halil İnalc1k, "The Ottoman State: Economy and Society, 1300-1600", An Economic and Social History of the Ottoman Empire, 13001914, editors: Halil İnalcık and Donald Quataert, Cambridge 1994, s. 126-130; Bahaeddin Yediyıldız, Ordu Kazası Sosyal Tarihi, Kültür ve Turizm Bakanlığı Yayınları, Ankara 1985, s. 8291; Margaret L. Venzke, "Aleppo's Mâlikâne-Divânî System", Journal of American Oriental Society, 106, 451-469; Vera P. Moutafchieva, Agrarian Relations in the Ottoman Empire in the 15th and 16th Centuries, New York 1988, s. 63; Mehmet Öz, XV-XVI. Yüzyıllarda Canik Sancağı, Türk Tarih Kurumu Yayını, Ankara 1999, s. 125,180 vd.; Oktay Özel, Changes in Settlement Patterns, Population and Society in Rural Anatolia: A Case Study of Amasya (1576-1642), Basılmamıs Doktora Tezi, Manchester Üniversitesi, Manchester 1993, s. 93-108; Ali Açıkel, Changes in Settlement Patterns, Population and Society in North Central Anatolia: A Case Study of the District (Kazâ) of Tokat (1574-1643), Basılmamış Doktora Tezi, Manchester Üniversitesi, Manchester 1999, s. 127-136, 200-203; Murat Hanilçe, XV ve XVI. Yüzyılda Zile Kazası (1455-1574), Basılmamış Doktora Tezi, Gaziosmanpaşa Üniversitesi Sosyal Bilimler Enstitüsü, Tokat 2014, s. 289-325.

| Gaziosmanpaşa Üniversitesi Sosyal Bilimler Araştırmaları Dergisi 


\section{Ali AÇIKEL}

aileden birkaç nesle ait sınırlı bilgiler içeren mufassal tapu tahrir defterleri kalmaktadır.

Tahrir defterlerine dayalı malikâne-divâni sistemi çalışmaları benzer bir sistemin Osmanlılardan önceki İslam devletlerinde (Selçuklular, Karamanlılar, Akkoyunlular ve Memluklular) de uygulandığını ortaya koymuştur. Osmanlılar eski Selçuklu topraklarının Orta ve Doğu Anadolu kısımlarını ilhak ettikleri zaman, bu sistemi ve bu sistem çerçevesinde mülkiyet haklarından yararlanan yerel aristokrasiyi mevcut buldular. Bu haklar yerel ailelere meşru Müslüman idareciler tarafından bahşedildiği için, Osmanlılar onları iptal edemeyerek olduğu gibi kabul etti. Ancak aynı zamanda esasen haracî toprak olan malikâne toprakların gelirleri üzerine "hükümet hissesi" olarak "divânî hisseyi" ilave etti ve bu hisseyi tımar olarak tahsis etti ${ }^{12}$. Bu bilgilerden Osmanlı dönemi malikâne sahiplerinin en azından bir kısmının kökenlerinin küçük beyliklere ya da Selçuklulara kadar geri gittiği ileri sürülebilir.

Yerel ailelerin Osmanlı öncesi devirlerde malikâne haklarını nasıl elde ettikleri konusuna gelince, akla iki ihtimal gelmektedir: Hazine'den satın alma ve Sultan ya da idarecinin temliki13. İlk olarak, Hazine'den para ile toprak alanların varlıklı insanlar oldukları kesindir. İkinci olarak şu üç ihtimal öne sürülebilir: 1- Bu malikâne sahipleri ya ilk fatihlerin torunları ya da bölgenin fethinden sonra bazı yerleşmelere iskân edilen aşiretlerin beyleri idiler; 2- Bir kısmı ikta olarak çok sayıda köyün malikâne hisseleri tahsis edilen Selçuklu, İlhanlı ve küçük beylikler döneminin idarî-askerî sınıf mensuplarının torunları olmalıdırlar; 3- Çok az bir kısmı ise idareciler tarafından temlik edilen topraklarda zaviyeler kuran şeyhler ya da şeyh ailelerine mensuptular ${ }^{14}$.

Abdülvehhab ve evlatlarının tarihi kimliği konusuna gelince, ilk olarak Abdülvehhab'in kim olduğu hususunda mevcut kaynaklardan herhangi bir bilgiye ulaşılamamıştır. 1455 yılı mufassal tahrir kayıtlarından Abdülvehhab'in Rum

\footnotetext{
12 İnalc1k, a.g.e., s. 127.

13 Osman Turan, Selçuklular ve İslamiyet, İstanbul 1971, s. 81-84; Beldicaeanu-Steinherr, a.g.m., s. 245-6, 267-8.

$14 \mathrm{Bu}$ üç kategoriye dair örnekler için bkz. Özel, a.g.t., s. 95-97; Mehmet Öz, Population, Taxation and Regional Economy in the District of Canik (According to Ottoman tahrir Defters, 1455-1576), Doktora Tezi, Cambridge Üniversitesi, Cambridge/İngiltere 1990, s. 195-96; Açıkel, a.g.t., s. 130.
} 


\section{Rum Eyaleti Evlatlık Vakıflarından Bir Örnek: Abdülvehhab Oğulları Evlatlık Vakfı}

eyaletinde Tokat kazasının Kafirni nahiyesi ve Sonisa kazasında birçok köy ve mezranın malikâne gelirini tasarruf ettiği ve bir kısım gelirlerini de evlatlık vakfa dönüştürdüğü anlaşılmaktadır15. Yine 1455 yılı kayıtlarında Abdullah adında bir oğlu olduğu görülmektedir ${ }^{16}$. 1530 yılı mufassal icmal defterinde Sonisa kazasının Ziğdi köyü malikâne gelirinin $3 / 4^{\prime}$ ünün Veli Çelebi'nin mülkü olduğu, Veli Çelebi'nin ise Abdülvehhab'ın oğlu olduğu belirtilmiştirit. 1574 yılı mufassal defterinde Sivas kazasının Hoşvenk/Hoşöbek köyü malikâne mutasarrıfı olarak “der dest-i Mahmud Çelebi v. Mehmed v. Veli Çelebi ez evlâd-1 Abdülvehhab" kaydı düşülmüştür ${ }^{18}$. Bu kayıttan Hoşvenk köyü malikânesinin mülkiyet üzere Abdülvehhab oğlu Veli Çelebi'nin oğlu Mehmed'in oğlu Mahmud'un üzerinde olduğu anlaşılmaktadır. Başka bir ifade ile Abdülvehhab'ın adı geçen köydeki mülkiyet haklarının üç nesil boyunca devam ettiği görülmektedir.

Abdülvehhab ve oğulları hakkında tahrir kayıtlarından elde edilen bilgiler ışığında, bu ailenin Osmanlı öncesi Kadı Burhaneddin Devleti'nde önemli idarî ve askerî görevler üstlendiği, Sivas, Tokat, Sonisa ve Çorumlu bölgelerinde birçok köyün malikâne haklarına sahip olduğu ve nihayet bu bölgelerin Osmanlı idaresine girdiğinde bu mülkiyet haklarının tanındığı ileri sürülebilir.

\section{3- Abdülvehhab'ın Kurduğu Evlatlık Vakfı}

Abdülvehhab, mülklerinden bir kısminı 1455 yılı öncesi evlatlık vakfa dönüştürmüştür. Evlatlık vakfın vakfiyesi mevcut olmadığından tam olarak ne zaman tesis edildiği ve hangi yerleşim yerlerinin malikâne gelirlerinin vakfedildiği bilinmemektedir. Bu vakfa dair ilk bilgilere Başbakanlık Osmanlı Arşivi (BOA) ile Tapu ve Kadastro Genel Müdürlüğü Kuyûd-1 Kadîme Arşivi'nde (TKGMM. KK) bulunan mufassal ve evkaf defterlerinden ulaşılmaktadır. Bu defterden 1455 yılına ait olanlar tarandığında aşağıda Tablo 1'de listelenen toplam yedi köyün Abdülvehhab'ın evlatlık vakfına gelir sağladığı tespit edilmiştir. Bu köylerden dört adedinin tam malikâne hisse, iki adedinin yarım malikâne hisse ve bir tanesinin ise çeyrek malikâne

${ }^{15}$ MC. 081, s. 39b; BOA. Td. 1083, s. 66a, 76a, 97b, 120a, 132b; BOA. Td. 1083, s. 137a; BOA. Td. 2, s. $603,607,609,611,614,615,630$.

${ }^{16}$ BOA. Td. 2, s. 603, 607 ve 630 .

${ }^{17}$ BOA. Td. 387, s. 531(neşredilen defter esas alınmıştır).

18 TKGM.KK. Td. 14, s. 40b.

| Gaziosmanpaşa Üniversitesi Sosyal Bilimler Araştırmaları Dergisi 


\section{Ali AÇIKEL}

hisse nispetinde vakfa katkı sağladıkları görülmektedir.

Tablo 1. Abdülvehhab Evlatlık Vakfının 1455 Yılı Akarları

\begin{tabular}{|c|c|c|c|c|c|}
\hline \multirow[t]{2}{*}{ Sancak/Kaza } & \multirow[t]{2}{*}{ Nahiye } & \multirow[t]{2}{*}{$\begin{array}{l}\text { Köy/Mezra } \\
\text { adı }\end{array}$} & \multicolumn{2}{|c|}{$\begin{array}{l}\text { Malikâne } \\
\text { geliri }\end{array}$} & \multirow[t]{2}{*}{ Referans } \\
\hline & & & Hisse & Akçe & \\
\hline Sivas/Sonisa & $\begin{array}{l}\text { Sahra-yı } \\
\text { Karakuş }\end{array}$ & Köstere & $1 / 2$ & 800 & $\begin{array}{l}\text { İB. AK. } \\
\text { MC }^{19} .081 \text {, } \\
\text { s. } 39 \text { b. }\end{array}$ \\
\hline Sivas/Sonisa & Sonisa & Derefte & $1 / 2$ & 0 & $\begin{array}{l}\text { BOA. Td. } \\
\text { 1083, s. } \\
\text { 132b. }\end{array}$ \\
\hline Sivas/Sonisa & Sonisa & Kışlakışamlı & $1 / 4$ & 0 & $\begin{array}{l}\text { BOA. Td. } \\
\text { 1083, s. } \\
\text { 137a. }\end{array}$ \\
\hline Sivas/Tokat & Kafirni & Kişla & Tam & 0 & $\begin{array}{l}\text { BOA. Td. } \\
2, \text { s. } 611 .\end{array}$ \\
\hline Sivas/Tokat & Kafirni & Kizilcasu & Tam & 0 & $\begin{array}{l}\text { BOA. Td. } \\
2, \text { s. } 614 .\end{array}$ \\
\hline Sivas/Tokat & Kafirni & Muhad & Tam & 0 & $\begin{array}{l}\text { BOA. Td. } \\
2, \text { s. } 609 .\end{array}$ \\
\hline Sivas/Tokat & Kafirni & Teknecik & Tam & 0 & $\begin{array}{l}\text { BOA. Td. } \\
2, \text { s. } 615 .\end{array}$ \\
\hline
\end{tabular}

1470'lerde II. Mehmet'in tımarlı asker sayısını artırmak için malikânelere ve evlatlık vakıflara müdahalesi olmuştur ${ }^{20}$. Bu müdahaleden Abdülvehhab'in mülkleri ve evlatlık vakfı da etkilenmiştir. Başbakanlık Osmanlı Arşivi'nde bulunan ve tahmini 1480 yılına tarihlenen 15 numaralı mufassal icmal defterindeki “Timar-1 Abdülvehhab ki vakf-1 evlâd deyu tasarruf ederlermiş tasarruf-ı sâbıkları üzere mutasarrıf olub sefer${ }^{19}$ İstanbul Belediyesi Atatürk Kitaplığı Muallim Cevdet tasnifi.
${ }^{20}$ Bu hususta yapılan birkaç önemli çalışma için bkz. Bistra Cvetkova, "Sur Certaines Reformes
du Régime Foncier au Temps de Mehmed II", JESHO, VI (1963), s. 104-120; Nicolae Beldiceanu,
"Recherches sur la Réforme Foncière de Mehmed II", Acta Historica, IV (1966), s. 27-39; Midhat
Sertoğlu, "Osmanlı İmparatorluğu'nda XV. ve XVI. Asırlarda Girişilen Toprak Reformları",
Belgelerle Türk Tarihi Dergisi, 35 (1970), s. 68-71; Vera P Moutafchieva, Agrarian Relations in the
Ottoman Empire in the 15th and $16^{\text {th }}$ Centuries, New York 1988; Halil İnalcık, "Rice Cultivation and
the Çeltükçi Re âyâ System in the Ottoman Empire", AO, VI (1982), 69-141; İnalcık, a.g.m., 1994,
s.1-410.

Gaziosmanpasa University Social Sciences Researches Journal 


\section{Rum Eyaleti Evlatlık Vakıflarından Bir Örnek: Abdülvehhab Oğulları Evlatlık Vakf1}

i zaferimize mülâzemet ideler." 21 başlık cümlesi bu müdahaleyi göstermektedir. Başlıktaki ifadeden Abdülvehhab evlatlık vakfına sefere katılma yükümlülüğü getirildiği anlaşılmaktadır. Defterde bu başlı̆̆ın altında Abdülvehhab'ın bütün malikâne hasılatı verilmiştir. Aşağıda verilen Tablo 2 bu malikâne hasıllarına göre hazırlanmıştır. Tablodaki verilerden Abdülvehhab oğulları vakfının Çorum ve Sivas'a bağlı kazalarda toplam 21 köy ve iki mezrada akarları bulunduğu anlaşılmaktadır. Tablo 1 ve Tablo 2'deki veriler mukayese edildiğinde, ilk olarak, 1455'te Sonisa kazasına bağlı üç köyün malikâne hisselerinin 1480'de yer almadığı görülmektedir. İkinci olarak, 1480 yılında Sivas'a bağlı 4 adet köyün 1455 yılında mevcut olmadığı anlaşılmaktadır. Bunun sebebi bu köylerden ikisinin (Murdarağaç ve Horsana) malikâne gelirlerinin 1455 yılında başka şahıslar üzerinde kayıtlı olması²2 ve diğer ikisinin (Hoşöbek ve Boynuzözü) ise kayıtlı bulunmamasıdır. Bu bilgiden hareketle, Abdülvehhab evladının 1480 yılı öncesinde Sivas kazasına bağlı adı geçen yerlerin malikâne gelirlerini satın alma yoluyla kendi vakıflarına aktardığı iddia edilebilir. Son olarak, Çorumlu kazasına bağlı Çonuş, Hızırbeysaray ve Tümsek (Mz.) yerleşim yerleri 1455'te mevcut olmayıp 1480' de kayıtlı bulunmaktadır.

Tablo 2. Abdülvehhab Evlatlık Vakfının 1480 Yılı Akarları

\begin{tabular}{|c|c|c|c|c|c|}
\hline \multirow{2}{*}{$\begin{array}{l}\text { Sancak/K } \\
\text { aza }\end{array}$} & \multirow[t]{2}{*}{ Nahiye } & \multirow{2}{*}{$\begin{array}{l}\text { Köy/Mezr } \\
\text { a adı }\end{array}$} & \multicolumn{2}{|c|}{ Malikâne } & \multirow[t]{2}{*}{ Referans } \\
\hline & & & $\begin{array}{l}\text { Hiss } \\
\mathrm{e}\end{array}$ & $\begin{array}{l}\text { Akç } \\
\text { e }\end{array}$ & \\
\hline Çorumlu & $\begin{array}{l}\text { Ağcames } \\
\text { cid }\end{array}$ & Çonuş & Tam & $\begin{array}{l}100 \\
0\end{array}$ & $\begin{array}{l}\text { BOA. Td. 15, s. } \\
165 .\end{array}$ \\
\hline Çorumlu & $\begin{array}{l}\text { A ğcames } \\
\text { cid }\end{array}$ & $\begin{array}{l}\text { Hizırbeysa } \\
\text { ray }\end{array}$ & Tam & $\begin{array}{l}230 \\
0\end{array}$ & $\begin{array}{l}\text { BOA. Td. 15, s. } \\
165 .\end{array}$ \\
\hline Çorumlu & $\begin{array}{l}\text { A ğcames } \\
\text { cid }\end{array}$ & $\begin{array}{l}\text { Tümsek } \\
\text { mz. }\end{array}$ & Tam & 50 & $\begin{array}{l}\text { BOA. Td. 15, s. } \\
165 .\end{array}$ \\
\hline $\begin{array}{l}\text { Sivas/Siv } \\
\text { as }\end{array}$ & Sivas & Barçınlu & Tam & 50 & $\begin{array}{l}\text { BOA. Td. 15, s. } \\
165 .\end{array}$ \\
\hline $\begin{array}{l}\text { Sivas/Siv } \\
\text { as }\end{array}$ & Sivas & Bingöl23 & Tam & 500 & $\begin{array}{l}\text { BOA. Td. 15, s. } \\
165 .\end{array}$ \\
\hline Sivas/Siv & Sivas & Boynuzöz & Tam & 80 & BOA. Td. 15, s. \\
\hline
\end{tabular}

${ }^{21}$ BOA. Td. 15, s. 165.

22 BOA. Td. 2, s. 530, 564.

${ }^{23}$ Bu köyün malikâne geliri 1530 yılı mufassal icmalinde Sivas'taki Daru'r-raha zaviyesi vakfına yazılmıştır (bkz. BOA. Td. 387, s. 501).

| Gaziosmanpaşa Üniversitesi Sosyal Bilimler Araştırmaları Dergisi 


\begin{tabular}{|c|c|c|c|c|c|}
\hline as & & $\ddot{\mathrm{u}}$ & & & 165. \\
\hline $\begin{array}{l}\text { Sivas/Siv } \\
\text { as }\end{array}$ & Sivas & Horsana & Tam & 0 & $\begin{array}{l}\text { BOA. Td. 15, s. } \\
165 .\end{array}$ \\
\hline $\begin{array}{l}\text { Sivas/Siv } \\
\text { as }\end{array}$ & Sivas & Hoşöbek & Tam & 50 & $\begin{array}{l}\text { BOA. Td. } 15, \text { s. } \\
165 .\end{array}$ \\
\hline $\begin{array}{l}\text { Sivas/Siv } \\
\text { as }\end{array}$ & Sivas & Esbil & Tam & 100 & $\begin{array}{l}\text { BOA. Td. 15, s. } \\
165 .\end{array}$ \\
\hline $\begin{array}{l}\text { Sivas/Siv } \\
\text { as }\end{array}$ & Sivas & Karaöyük & Tam & 200 & $\begin{array}{l}\text { BOA. Td. } 15, \text { s. } \\
165 .\end{array}$ \\
\hline $\begin{array}{l}\text { Sivas/Siv } \\
\text { as }\end{array}$ & Sivas & $\begin{array}{l}\text { Murdară̆ } \\
\text { aç }\end{array}$ & Tam & 100 & $\begin{array}{l}\text { BOA. Td. 15, s. } \\
165 .\end{array}$ \\
\hline $\begin{array}{l}\text { Sivas/To } \\
\text { kat }\end{array}$ & Kafirni & Avc1 & Tam & 180 & $\begin{array}{l}\text { BOA. Td. 15, s. } \\
165 .\end{array}$ \\
\hline $\begin{array}{l}\text { Sivas/To } \\
\text { kat }\end{array}$ & Kafirni & Buldacı & Tam & 880 & $\begin{array}{l}\text { BOA. Td. } 15, \text { s. } \\
165 .\end{array}$ \\
\hline $\begin{array}{l}\text { Sivas/To } \\
\text { kat }\end{array}$ & Kafirni & Kışla & Tam & 300 & $\begin{array}{l}\text { BOA. Td. 15, s. } \\
165 .\end{array}$ \\
\hline $\begin{array}{l}\text { Sivas/To } \\
\text { kat }\end{array}$ & Kafirni & Kizilcasu & Tam & 600 & $\begin{array}{l}\text { BOA. Td. } 15 \text {, s. } \\
165 .\end{array}$ \\
\hline $\begin{array}{l}\text { Sivas/To } \\
\text { kat }\end{array}$ & Kafirni & Küplüce & Tam & 100 & $\begin{array}{l}\text { BOA. Td. 15, s. } \\
165 .\end{array}$ \\
\hline $\begin{array}{l}\text { Sivas/To } \\
\text { kat }\end{array}$ & Kafirni & Muhad & Tam & $\begin{array}{l}286 \\
0\end{array}$ & $\begin{array}{l}\text { BOA. Td. 15, s. } \\
165 .\end{array}$ \\
\hline $\begin{array}{l}\text { Sivas/To } \\
\text { kat }\end{array}$ & Kafirni & Taşlısekü & Tam & 100 & $\begin{array}{l}\text { BOA. Td. 15, s. } \\
165 .\end{array}$ \\
\hline $\begin{array}{l}\text { Sivas/To } \\
\text { kat }\end{array}$ & Kafirni & Teknecik & Tam & 100 & $\begin{array}{l}\text { BOA. Td. 15, s. } \\
165 .\end{array}$ \\
\hline $\begin{array}{l}\text { Sivas/Tur } \\
\text { hal }\end{array}$ & Aştağul & $\begin{array}{l}\text { Avşacıklar } \\
\text { mz. }\end{array}$ & Tam & 330 & $\begin{array}{l}\text { BOA. Td. 15, s. } \\
165 .\end{array}$ \\
\hline $\begin{array}{l}\text { Sivas/Tur } \\
\text { hal }\end{array}$ & Aştağul & Boğabağ1 & Tam & $\begin{array}{l}258 \\
5 \\
\end{array}$ & $\begin{array}{l}\text { BOA. Td. 15, s. } \\
165 .\end{array}$ \\
\hline $\begin{array}{l}\text { Sivas/Tur } \\
\text { hal }\end{array}$ & Aştağul & Yalıncak & Tam & $\begin{array}{l}100 \\
0\end{array}$ & $\begin{array}{l}\text { BOA. Td. 15, s. } \\
165 .\end{array}$ \\
\hline $\begin{array}{l}\text { Sivas/Tur } \\
\text { hal }\end{array}$ & Aştağul & Mühreler & Tam & 600 & $\begin{array}{l}\text { BOA. Td. 15, s. } \\
165\end{array}$ \\
\hline Toplam & \multicolumn{5}{|c|}{$[14065] 14289$} \\
\hline
\end{tabular}




\section{Rum Eyaleti Evlatlık Vakıflarından Bir Örnek: Abdülvehhab Oğulları Evlatlık Vakfı}

1485 yılına ait 19 numaralı tapu defteri kayıtları incelendiğinde aşağıda Tablo 3'de listelenen toplam 12 köy ile bir mezranın Abdülvehhab'ın evlatlık vakfına gelir sağladığ 1 tespit edilmiştir. Bu yerleşim yerlerinin malikâne gelirlerinin tamamının adı geçen vakfa ait olduğu görülmektedir. Tablo 1, Tablo 2 ve Tablo 3'deki veriler mukayese edildiğinde, ilk olarak, 1480'de Turhal kazasına tabi Avşacıklar (mz.), Boğabağı, Yalıncak ve Mühreler ile Çorumlu kazasına bağlı Çonuş, Hızırbeysaray ve Tümsek (mz.) yerleşim yerlerinin 1485 yılı defterinde yer almadığı görülmektedir. Son olarak, Tablo 1'de yer alan Sonisa kazasına ait üç köyün 1480'de olduğu gibi,1485 defterlerinde de yer almadığı anlaşılmaktadır. Bunun başlıca nedeni Sonisa kazasının 1485 yılına ait mufassal defterinin günümüze ulaşmamış olmasıdır.

Tablo 3. Abdülvehhab Evlatlık Vakfının 1485 Yılı Akarları

\begin{tabular}{|l|l|l|l|l|}
\hline Sancak/Kaza & $\begin{array}{l}\text { Nahiy } \\
\text { e }\end{array}$ & $\begin{array}{l}\text { Köy/Mezra } \\
\text { adı }\end{array}$ & $\begin{array}{l}\text { Malikâne } \\
\text { Hissesi }\end{array}$ & Referans \\
\hline Sivas/Sivas & Sivas & Boynuzözü & Tam & BOA. Td. 19, s. 470. \\
\hline Sivas/Sivas & Sivas & Horsana & Tam & BOA. Td. 19, s. 488. \\
\hline Sivas/Sivas & Sivas & Hoşöbek & Tam & BOA. Td. 19, s. 461. \\
\hline Sivas/Sivas & Sivas & Esbil & Tam & BOA. Td. 19, s. 470. \\
\hline Sivas/Sivas & Sivas & $\begin{array}{l}\text { Murdarağa } \\
\text { ç }\end{array}$ & Tam & BOA. Td. 19, s. 434. \\
\hline Sivas/Tokat & Kafirni & Avcı (mz.) & Tam & BOA. Td. 19, s. 516. \\
\hline Sivas/Tokat & Kafirni & Buldacı & Tam & BOA. Td. 19, s. 516. \\
\hline Sivas/Tokat & Kafirni & Kişla & Tam & BOA. Td. 19, s. 517. \\
\hline Sivas/Tokat & Kafirni & Kizılcasu & Tam & BOA. Td. 19, s. 521. \\
\hline Sivas/Tokat & Kafirni & Küplüce & Tam & BOA. Td. 19, s. 525. \\
\hline Sivas/Tokat & Kafirni & Muhad & Tam & BOA. Td. 19, s. 516. \\
\hline Sivas/Tokat & Kafirni & Taşlısekü & Tam & BOA. Td. 19, s. 504. \\
\hline Sivas/Tokat & Kafirni & Teknecik & Tam & BOA. Td. 19, s. 504. \\
\hline
\end{tabular}

1520 yılına ait 54 ve 79 numaralı tapu defterleri incelendiğinde aşağıda Tablo 4'te listelenen toplam 11 köy ile üç mezranın malikâne gelirlerinin Abdülvehhab'ın evlatlık vakfına yazıldığı tespit edilmiştir. Bu yerleşim yerlerinden 10'unun malikâne gelirlerinin tamamı, ikisinin çeyrek malikânesi ve kalan birisinin ise $2 / 7$ hisse malikânesinin adı geçen vakfa ait olduğu görülmektedir. Tablo 2, Tablo 3 ve Tablo 4'teki veriler mukayese edildiğinde, ilk olarak, 1480 ve 1485 yıllarında Sivas'a bağlı beş köyün (Boynuzözü, Horsana, Hoşöbek, Esbil ve Murdarağaç) 1520 yılında mevcut olmadığı anlaşılmaktadır. Bunun muhtemel sebebi Sivas kazasının 1520 yılına ait mufassal tapu tahrir defterinin günümüze ulaşmamış olmasıdır. İkinci olarak, Tablo 1

| Gaziosmanpaşa Üniversitesi Sosyal Bilimler Araştırmaları Dergisi 


\section{Ali AÇIKEL}

ve Tablo 3'te yer almayan Turhal kazasına ait üç köy (Boğabağı, Yalıncak ve Mühreler) ve bir mezranın (Avşacıklar) 1520'de yer aldığı görülmektedir. Üçüncü olarak, 1455 yılı defterinde yer alan Sonisa kazasına tabi Derefte ve Kışlakışamlı köyleri, 1520 defterinde tekrar Abdülvehhab evlatlık vakfı akarları arasında gösterilmiştir. Son olarak, Tablo 1, Tablo 2 ve Tablo 3 'te yer almayan Niksar kazasina tabi Kodokos köyünün 1520 yılı mufassal defterinde yer aldığ1 görülmektedir. Bu bilgilerden, Abdülvehhab evladının 1520 yılı öncesinde Niksar kazasına tabi bir köyün malikânesini satın alma yoluyla kendi vakıflarına aktarmış olduğu ileri sürülebilir.

Tablo 4. Abdülvehhab Evlatlık Vakfının 1520 Yılı Akarları

\begin{tabular}{|c|c|c|c|c|c|}
\hline Sancak/Kaza & Nahiye & $\begin{array}{l}\text { Köy/Mezra } \\
\text { adı }\end{array}$ & $\begin{array}{l}\text { Malik } \\
\text { geliri }\end{array}$ & & Referans \\
\hline Sivas/Niksar & Avlun & Kodokos & $2 / 7$ & 0 & $\begin{array}{l}\text { BOA. Td. } 54, \text { s. } \\
149 .\end{array}$ \\
\hline Sivas/Sonisa & Sonisa & Derefte & $1 / 4$ & 0 & $\begin{array}{l}\text { BOA. Td. } 54, \text { s. } \\
36 .\end{array}$ \\
\hline Sivas/Sonisa & Sonisa & Kışlakışamlı & $1 / 4$ & 0 & $\begin{array}{l}\text { BOA. Td. } 54, \text { s. } \\
40 .\end{array}$ \\
\hline Sivas/Tokat & Kafirni & Avc1 (mz.) & Tam & 0 & $\begin{array}{l}\text { BOA. Td. } 79, \text { s. } \\
77 .\end{array}$ \\
\hline Sivas/Tokat & Kafirni & Buldacı & Tam & 0 & $\begin{array}{l}\text { BOA. Td. } 79, \text { s. } \\
77 .\end{array}$ \\
\hline Sivas/Tokat & Kafirni & Kışla & Tam & 0 & $\begin{array}{l}\text { BOA. Td. } 79, \text { s. } \\
79 .\end{array}$ \\
\hline Sivas/Tokat & Kafirni & Kizılcasu & Tam & 700 & $\begin{array}{l}\text { BOA. Td. } 79, \text { s. } \\
84 .\end{array}$ \\
\hline Sivas/Tokat & Kafirni & Küplüce(mz.) & Tam & 0 & $\begin{array}{l}\text { BOA. Td. } 79, \text { s. } \\
89 .\end{array}$ \\
\hline Sivas/Tokat & Kafirni & Muhad & Tam & 0 & $\begin{array}{l}\text { BOA. Td. } 79, \text { s. } \\
78 .\end{array}$ \\
\hline Sivas/Tokat & Kafirni & Teknecik & Tam & 0 & $\begin{array}{l}\text { BOA. Td. 79, s. } \\
63 .\end{array}$ \\
\hline Sivas/Turhal & Turhal & $\begin{array}{l}\text { Avşacıklar(m } \\
\text { z.) }\end{array}$ & Tam & 0 & $\begin{array}{l}\text { BOA. Td. 79, } \\
\text { s.330. }\end{array}$ \\
\hline Sivas/Turhal & Turhal & Boğabağ1 & Tam & 0 & $\begin{array}{l}\text { BOA. Td. } 79, \\
\text { s.330. }\end{array}$ \\
\hline Sivas/Turhal & Turhal & Yalıncak & Tam & 0 & $\begin{array}{l}\text { BOA. Td. 79, } \\
\text { s.331. }\end{array}$ \\
\hline Sivas/Turhal & Mecidözü & Mühreler & Tam & 0 & $\begin{array}{l}\text { BOA. Td. 79, } \\
\text { s.342. }\end{array}$ \\
\hline
\end{tabular}




\section{Rum Eyaleti Evlatlık Vakıflarından Bir Örnek: Abdülvehhab Oğulları Evlatlık Vakfı}

Karaman ve Rum eyaletlerinin 1520-1523 dönemi mufassal tahrirlerinin geniş bir icmali olan ve 1530 yılına tarihlenen 387 numaralı tapu defteri Abdülvehhab evlatlık vakfına ait toplam 18 köy ile iki mezranın malikâne gelirlerini vermektedir. Bu yerleşim yerlerinin isimleri ve malikâne gelirleri aşağıda Tablo $4^{\prime}$ te listelenmiştir. Tablodan anlaşılacağı üzere, bu yerleşim yerlerinden 16'sının malikâne gelirlerinin tamamı, birinin yarım malikânesi, ikisinin çeyrek malikânesi ve kalan birisinin ise 2/7 malikâne hissesi adı geçen vakfa toplamda 13749 akçe katkı sağlamıştır. Tablo 4 ve Tablo 5'teki veriler mukayese edildiğinde, ilk olarak, veri eksikliği nedeniyle 1520 yılı için tespit edemediğimiz Sivas'a bağlı 4 adet köyün (Boynuzözü, Horsana, Hoşöbek ve Murdarağaç) 1530 yılında kayıtlı olduğu anlaşılmaktadır. İkinci olarak, veri eksikliği nedeniyle Tablo 1, Tablo 3 ve Tablo 4'de yer almayan Çorumlu sancağına tabi Divan-1 Emlak nahiyesine ait iki köyün (Çonuş ve Hızırbey) 1530 yılı defterinde yer aldığ görülmektedir. Son olarak, 1480 yılı defterinde yer alan Çorumlu kazası Aştağul nahiyesine tabi Tümsek mezrası; Sivas kazasına tabi Bingöl24 köyü; Kafirni nahiyesine bağlı Küplüce köyü 1530 defterinde belirtilmemiştir.

Tablo 5. Abdülvehhab Evlatlık Vakfının 1530 Yılı Akarları

\begin{tabular}{|l|l|l|l|l|l|}
\hline Sancak/Kaza & Nahiye & \multirow{2}{*}{$\begin{array}{l}\text { Köy/Mez } \\
\text { ra adı }\end{array}$} & $\begin{array}{l}\text { Malikane } \\
\text { geliri }\end{array}$ & \multirow{2}{*}{ Referans } \\
\cline { 5 - 6 } & & & Hisse & Akçe & \\
\hline Çorumlu & $\begin{array}{l}\text { D. } \\
\text { Emlak }\end{array}$ & Çonuş & Tam & 400 & $\begin{array}{l}\text { BOA. Td. 387, s. } \\
\text { 395. }\end{array}$ \\
\hline Çorumlu & $\begin{array}{l}\text { D. } \\
\text { Emlak }\end{array}$ & Hızırbey & Tam & 4036 & $\begin{array}{l}\text { BOA. Td. 387, s. } \\
\text { 395. }\end{array}$ \\
\hline Sivas/Niksar & Niksar & Kodokos & $2 / 7$ & 157 & $\begin{array}{l}\text { BOA. Td. 387, s. } \\
540 .\end{array}$ \\
\hline Sivas/Sivas & Sivas & $\begin{array}{l}\text { Boynuzöz } \\
\text { ü }\end{array}$ & Tam & 410 & $\begin{array}{l}\text { BOA. Td. 387, s. } \\
517 .\end{array}$ \\
\hline Sivas/Sivas & Sivas & Horsana & Tam & 760 & $\begin{array}{l}\text { BOA. Td. 387, s. } \\
512 .\end{array}$ \\
\hline Sivas/Sivas & Sivas & Hoşöbeği & Tam & 230 & $\begin{array}{l}\text { BOA. Td. 387, s. } \\
499 .\end{array}$ \\
\hline Sivas/Sivas & Sivas & $\begin{array}{l}\text { Murdarağ } \\
\text { aç }\end{array}$ & Tam & 430 & $\begin{array}{l}\text { BOA. Td. 387, s. } \\
512 .\end{array}$ \\
\hline Sivas/Sonisa & Sonisa & Derefte & $1 / 4$ & 337 & $\begin{array}{l}\text { BOA. Td. 387, s. } \\
533 .\end{array}$ \\
\hline
\end{tabular}

${ }^{24}$ Bu köyün malikâne geliri 1530 yılı mufassal icmalinde Sivas'taki Daru'r-raha zaviyesi vakfına yazılmıştır (bkz. BOA. Td. 387, s. 501).

| Gaziosmanpaşa Üniversitesi Sosyal Bilimler Araştırmaları Dergisi 


\section{Ali AÇIKEL}

\begin{tabular}{|l|l|l|l|l|l|}
\hline Sivas/Sonisa & Sonisa & $\begin{array}{l}\text { Kişlakışa } \\
\text { mlı }\end{array}$ & $1 / 4$ & 155 & $\begin{array}{l}\text { BOA. Td. 387, s. } \\
534 .\end{array}$ \\
\hline Sivas/Sonisa & Karakuş & Köstere & $1 / 2$ & 55 & $\begin{array}{l}\text { BOA. Td. 387, s. } \\
540 .\end{array}$ \\
\hline Sivas/Tokat & Kafirni & $\begin{array}{l}\text { Avc1 } \\
\text { (mz.) }\end{array}$ & Tam & 422 & $\begin{array}{l}\text { BOA. Td. 387, s. } \\
441 .\end{array}$ \\
\hline Sivas/Tokat & Kafirni & Buldac1 & Tam & 350 & $\begin{array}{l}\text { BOA. Td. 387, s. } \\
441 .\end{array}$ \\
\hline Sivas/Tokat & Kafirni & Kışla & Tam & 260 & $\begin{array}{l}\text { BOA. Td. 387, s. } \\
441 .\end{array}$ \\
\hline Sivas/Tokat & Kafirni & Kızılca & Tam & 700 & $\begin{array}{l}\text { BOA. Td. 387, s. } \\
441 .\end{array}$ \\
\hline Sivas/Tokat & Kafirni & Muhad & Tam & 280 & $\begin{array}{l}\text { BOA. Td. 387, s. } \\
441 .\end{array}$ \\
\hline Sivas/Tokat & Kafirni & Teknecik & Tam & 355 & $\begin{array}{l}\text { BOA. Td. 387, s. } \\
439 .\end{array}$ \\
\hline Sivas/Turhal & Turhal & $\begin{array}{l}\text { Avşacıkla } \\
\text { (mz.) }\end{array}$ & Tam & 790 & $\begin{array}{l}\text { BOA. Td. 387, s. } \\
477 .\end{array}$ \\
\hline Sivas/Turhal & Turhal & Boğabağ1 & Tam & 1832 & $\begin{array}{l}\text { BOA. Td. 387, s. } \\
477 .\end{array}$ \\
\hline Sivas/Turhal & Turhal & Yalıncak & Tam & 830 & $\begin{array}{l}\text { BOA. Td. 387, s. } \\
477 .\end{array}$ \\
\hline Sivas/Turhal & $\begin{array}{l}\text { Mecidöz } \\
\text { ü }\end{array}$ & Mühreler & Tam & 960 & $\begin{array}{l}\text { BOA. Td. 387, s. } \\
479 .\end{array}$ \\
\hline Toplam & & & & 13749 & \\
\hline
\end{tabular}

1574 ve 1577 y1llarına ait 10, 12, 14 ve 38(54) numaralı tapu defterleri incelendiğinde aşağıda Tablo $6^{\prime}$ da listelenen toplam 18 köy ile dört mezranın malikâne gelirlerinin Abdülvehhab'ın evlatlık vakfına yazıldığı tespit edilmiştir. Bu yerleşim yerlerinden 18'inin malikâne gelirlerinin tamamı, ikisinin çeyrek malikânesi, diğer birinin yarım malikânesi ve kalan birisinin ise 2/7 malikâne hissesinin adı geçen vakfa ait olduğu görülmektedir. Tablo 5 ve Tablo 6 'daki veriler mukayese edildiğinde, 1530 yılı defterinde Abdülvehhab evlatlık vakfına ait bütün yerleşim yerleri 1574-1577 yılları defterlerinde aynen yazılmakla birlikte iki mezranın (Çorumlu kazası Divan-1 emlak nahiyesine tabi Kicik ve Tokat kazası Kafirni nahiyesine bağlı Küplüce) da malikânesi ilave edilmiştir. 


\section{Rum Eyaleti Evlatlık Vakıflarından Bir Örnek: Abdülvehhab Oğulları Evlatlık Vakf1}

Tablo 6. Abdülvehhab Evlatlık Vakfının 1574-1577 Yılları Akarları

\begin{tabular}{|c|c|c|c|c|c|}
\hline \multirow[t]{2}{*}{ Sancak/Kaza } & \multirow[t]{2}{*}{ Nahiye } & \multirow[t]{2}{*}{$\begin{array}{l}\text { Köy/Mezra } \\
\text { adı }\end{array}$} & \multicolumn{2}{|c|}{$\begin{array}{l}\text { Malikane } \\
\text { geliri }\end{array}$} & \multirow[t]{2}{*}{ Referans } \\
\hline & & & Hisse & Akçe & \\
\hline Çorumlu/D. Emlak & D. Emlak & $\begin{array}{l}\text { Çonuş/Dol } \\
\text { oş }\end{array}$ & Tam & 0 & $\begin{array}{l}\text { TKGM.KK. Td. } \\
38 / 54, \text { s. } 64 a .\end{array}$ \\
\hline Çorumlu/. Emlak & D. Emlak & $\begin{array}{l}\text { Hizırbeysar } \\
\text { ay1 }\end{array}$ & Tam & 0 & $\begin{array}{l}\text { TKGM.KK. Td. } \\
\text { 38/54, s. } 48 b .\end{array}$ \\
\hline Çorumlu/D. Emlak & D. Emlak & Kicik (mz.) & Tam & 0 & $\begin{array}{l}\text { TKGM.KK. Td. } \\
\text { 38/54, s. } 67 a .\end{array}$ \\
\hline Sivas/Niksar & Niksar & Kodokos & $2 / 7$ & 0 & $\begin{array}{l}\text { TKGM.KK. Td. 10, } \\
\text { s. 39a. }\end{array}$ \\
\hline Sivas/Sivas & Sivas & $\begin{array}{l}\text { Boynuzözü } \\
(\mathrm{mz} .)\end{array}$ & Tam & 0 & $\begin{array}{l}\text { TKGM.KK. Td. 14, } \\
\text { s. } 49 \text { b. }\end{array}$ \\
\hline Sivas/Sivas & Sivas & Horsana & Tam & 0 & $\begin{array}{l}\text { TKGM.KK. Td. } 14 \text {, } \\
\text { s. } 65 \text { a. }\end{array}$ \\
\hline Sivas/Sivas & Sivas & $\begin{array}{l}\text { Hoşöbek/ } \\
\text { Hoşvenk }\end{array}$ & Tam & 0 & $\begin{array}{l}\text { TKGM.KK. Td. 14, } \\
\text { s. } 40 \text { b. }\end{array}$ \\
\hline Sivas/Sivas & Sivas & Murdarağaç & Tam & 0 & $\begin{array}{l}\text { TKGM.KK. Td. 14, } \\
\text { s. } 43 \text { a. }\end{array}$ \\
\hline Sivas/Sonisa & Sonisa & Derefte & $1 / 4$ & 0 & $\begin{array}{l}\text { TKGM.KK. Td. 12, } \\
\text { s. } 81 \text { b. }\end{array}$ \\
\hline Sivas/Sonisa & Sonisa & Kışlakışamlı & $1 / 4$ & 0 & $\begin{array}{l}\text { TKGM.KK. Td. } 12, \\
\text { s. } 20 \text { a. }\end{array}$ \\
\hline Sivas/Sonisa & Karakuş & Köstere & $1 / 2$ & 300 & $\begin{array}{l}\text { TKGM.KK. Td. 12, } \\
\text { s. } 71 \text { a. }\end{array}$ \\
\hline Sivas/Tokat & Kafirni & $\operatorname{Avc1}(\mathrm{mz})$ & Tam & 0 & $\begin{array}{l}\text { TKGM.KK. Td. 14, } \\
\text { s. } 219 \text { b. }\end{array}$ \\
\hline Sivas/Tokat & Kafirni & Buldacı & Tam & 0 & $\begin{array}{l}\text { TKGM.KK. Td. 14, } \\
\text { s. } 221 \text { b. }\end{array}$ \\
\hline Sivas/Tokat & Kafirni & Kişla & Tam & 0 & $\begin{array}{l}\text { TKGM.KK. Td. 14, } \\
\text { s. } 219 \text { a. }\end{array}$ \\
\hline Sivas/Tokat & Kafirni & Kizilcasu & Tam & 0 & $\begin{array}{l}\text { TKGM.KK. Td. } 14 \text {, } \\
\text { s. } 215 \text { a. }\end{array}$ \\
\hline Sivas/Tokat & Kafirni & $\begin{array}{l}\text { Küplüce } \\
(\mathrm{mz} .)\end{array}$ & Tam & 0 & $\begin{array}{l}\text { TKGM.KK. Td. 14, } \\
\text { s. 219a. }\end{array}$ \\
\hline Sivas/Tokat & Kafirni & Muhad & Tam & 0 & $\begin{array}{l}\text { TKGM.KK. Td. 14, } \\
\text { s. } 218 \text { a. }\end{array}$ \\
\hline Sivas/Tokat & Kafirni & Teknecik & Tam & 0 & $\begin{array}{l}\text { TKGM.KK. Td. 14, } \\
\text { s. } 205 \text { b. }\end{array}$ \\
\hline Sivas/ Mecidözü & Mecidözü & Avşacıklar & Tam & 0 & $\begin{array}{l}\text { TKGM.KK. Td. } \\
\text { 12/178, s. } 125 b .\end{array}$ \\
\hline Sivas/Turhal & Turhal & Boğabağ1 & Tam & 0 & TKGM.KK. Td. 12, \\
\hline
\end{tabular}

| Gaziosmanpaşa Üniversitesi Sosyal Bilimler Araştırmaları Dergisi 


\section{Ali AÇIKEL}

\begin{tabular}{|c|c|c|c|c|c|}
\hline & & & & & $\begin{array}{l}\text { s. 101a; } \\
\text { TKGM.KK. Td. } \\
\text { 583, s. 67a. }\end{array}$ \\
\hline Sivas/ Mecidözü & Mecidözü & Yalıncak & Tam & 830 & $\begin{array}{l}\text { TKGM.KK. Td. } \\
\text { 12/178, s. 125b. }\end{array}$ \\
\hline Sivas/Mecidözü & Mecidözü & Mühreler & Tam & 0 & $\begin{array}{l}\text { TKGM.KK. Td. 12, } \\
\text { s. 109b. }\end{array}$ \\
\hline Toplam & & & & 1130 & \\
\hline
\end{tabular}

\section{4- Abdülvehhab Oğulları Mülkleri}

Abdülvehhab'ın Sivas eyaleti dahilinde kurduğu evlatlık vakfına tahsis etmeyip mülk olarak evlatlarına bıraktığı az sayıda yerleşim yeri malikane gelirleri de bulunmaktadır. İncelediğimiz tapu tahrir defterlerinde mülk olarak kayıtlı malikâne gelirlerinin zamanla azaldığı görülmektedir. Elimizdeki en eski tarihli tapu tahrir defterine göre, Abdülvehhab oğullarına ait mülkler aşağıda Tablo 7'de listelenmiştir. Buna göre, Taşabad, Sonisa ve Kafirni nahiyelerine bağlı toplam altı köy ile bir mezranın malikâne gelirleri Abdülvehhab oğullarının tasarrufundadır.

Tablo 7. Abdülvehhab oğulları mülkleri (1455)

\begin{tabular}{|l|l|l|l|l|}
\hline Sancak/Kaza & Nahiye & $\begin{array}{l}\text { Köy/Mezra } \\
\text { ad1 }\end{array}$ & $\begin{array}{l}\text { Malikâne } \\
\text { hissesi }\end{array}$ & Referans \\
\hline Sivas/Sonisa & Taşabad & Bidevi & Tam & $\begin{array}{l}\text { BOA. Td. } \\
1083, \text { s. 66a. }\end{array}$ \\
\hline Sivas/Sonisa & Taşabad & Hazımköy & Tam & $\begin{array}{l}\text { BOA. Td. } \\
1083, \text { s. 76a. }\end{array}$ \\
\hline Sivas/Sonisa & Sonisa & Ziğdi & $3 / 4$ & $\begin{array}{l}\text { BOA. Td. } \\
1083, \text { s. 97b. }\end{array}$ \\
\hline Sivas/Sonisa & Sonisa & Ziyare & Tam & $\begin{array}{l}\text { BOA. Td. } \\
1083, \text { s. 120a. }\end{array}$ \\
\hline Sivas/Tokat & Kafirni & Küplüce & Tam & $\begin{array}{l}\text { BOA. Td. 2, s. } \\
603 .\end{array}$ \\
\hline Sivas/Tokat & Kafirni & Buldac1 & Tam & $\begin{array}{l}\text { BOA. Td. 2, s. } \\
607 .\end{array}$ \\
\hline Sivas/Tokat & Kafirni & Avc1 (mz) & Tam & $\begin{array}{l}\text { BOA. Td. 2, s. } \\
630 .\end{array}$ \\
\hline
\end{tabular}

1485 yılına ait tapu tahrir defteri incelendiğinde, Abdülvehhab oğullarının mülk olarak Sivas kazasına tabi sadece iki köyün (Çöplü yarım hisse, Karaöyük tam 


\section{Rum Eyaleti Evlatlık Vakıflarından Bir Örnek: Abdülvehhab Oğulları Evlatlık Vakf1}

hisse) malikânesini tasarruf ettikleri görülmektedir (bkz. Tablo 7). 1455 yılı defterinde malikâne mülk olan Kafirni nahiyesine tabi Küplüce ve Buldacı köyleri ile Avc1 mezrasının 1485'te Abdülvehhab'ın evlatlık vakfına aktarıldığı anlaşılmaktadır. 1515 yılına ait Sonisa kazası tapu tahrir defterinde ise sadece Ziyare köyünün malikâne geliri Abdülvehhab evladı mülkü olarak belirtilmiştir25.

Tablo 8. Abdülvehhab oğulları mülkleri (1485)

\begin{tabular}{|l|l|l|l|l|}
\hline Sancak/Kaza & Nahiye & $\begin{array}{l}\text { Köy/Mezra } \\
\text { adı }\end{array}$ & $\begin{array}{l}\text { Malikâne } \\
\text { Hisse }\end{array}$ & Referans \\
\hline Sivas/Sivas & Sivas & Çöplü & $1 / 2$ & $\begin{array}{l}\text { BOA. Td. 19, s. } \\
433 .\end{array}$ \\
\hline Sivas/Sivas & Sivas & Karaöyük & Tam & $\begin{array}{l}\text { BOA. Td. 19, s. } \\
474 .\end{array}$ \\
\hline
\end{tabular}

1530 yılı tapu tahrir defteri incelendiğinde, evvela Abdülvehhab oğullarının mülk olarak Sivas ve Sonisa kazalarına tabi toplam sekiz yerleşim yerinin malikânesini tasarruf ettikleri görülmektedir (bkz. Tablo 8). Ayrıca, 1480 yılı defterinde malikâne mülk olan Sivas kazasına bağlı Barçın ve Eslim köylerinin 1530'da Abdülvehhab'ın evlatlık vakfına aktarıldığı anlaşılmaktadır.

Tablo 9. Abdülvehhab oğulları mülkleri (1530)

\begin{tabular}{|l|l|l|l|l|l|}
\hline Sancak/Kaza & Nahiye & \multirow{2}{*}{$\begin{array}{l}\text { Köy/Mezra } \\
\text { adı }\end{array}$} & \multicolumn{2}{|l|}{$\begin{array}{l}\text { Malikane } \\
\text { geliri }\end{array}$} & Referans \\
\cline { 4 - 5 } & & & Hisse & Akçe & \\
\hline Sivas/Sivas & Sivas & Barçın(mz) & Tam & 490 & $\begin{array}{l}\text { BOA. Td. } \\
\text { 387, s. 510. }\end{array}$ \\
\hline Sivas/Sivas & Sivas & Çöplü & $1 / 2$ & 50 & $\begin{array}{l}\text { BOA. Td. } \\
\text { 387, s. 505. }\end{array}$ \\
\hline Sivas/Sivas & Sivas & Estik/Eslim & Tam & 839 & $\begin{array}{l}\text { BOA. Td. } \\
\text { 387, s. 510. }\end{array}$ \\
\hline Sivas/Sivas & Sivas & Karaöyük & Tam & 406 & $\begin{array}{l}\text { BOA. Td. } \\
\text { 387, s. 510. }\end{array}$ \\
\hline Sivas/Sonisa & Taşabad & Bidevi & Tam & 1925 & $\begin{array}{l}\text { BOA. Td. } \\
\text { 387, s. 535. }\end{array}$ \\
\hline Sivas/Sonisa & Taşabad & Hazım & Tam & 800 & $\begin{array}{l}\text { BOA. Td. } \\
\text { 387, s. 530. }\end{array}$ \\
\hline
\end{tabular}

25 BOA. Td. 54, s. 26.

| Gaziosmanpaşa Üniversitesi Sosyal Bilimler Araştırmaları Dergisi 


\section{Ali AÇIKEL}

\begin{tabular}{|c|c|c|c|c|c|}
\hline Sivas/Sonisa & Sonisa & Zikdi & $3 / 4$ & 2418 & $\begin{array}{l}\text { BOA. Td. } \\
387, \text { s. } 531 .\end{array}$ \\
\hline Sivas/Sonisa & Sonisa & Zipare & Tam & 960 & $\begin{array}{l}\text { BOA. Td. } \\
387, \text { s. } 533 .\end{array}$ \\
\hline Toplam & & & & 7888 & \\
\hline
\end{tabular}

1574-1577 yılları tapu tahrir defterleri incelendiğinde, Abdülvehhab oğullarının mülk olarak Sivas ve Sonisa kazalarına tabi toplam sekiz yerleşim yerinin malikâne gelirini tasarruf ettikleri görülmektedir (bkz. Tablo 9). Bu yerleşim yerleri de 1530 defterinde zikredilenlerin aynısıdır.

Tablo 10. Abdülvehhab oğulları mülkleri (1574-77)

\begin{tabular}{|c|c|c|c|c|}
\hline Sancak/Kaza & Nahiye & $\begin{array}{l}\text { Köy/Mezra } \\
\text { ad1 }\end{array}$ & $\begin{array}{l}\text { Malikane } \\
\text { hissesi }\end{array}$ & Referans \\
\hline Sivas/Sivas & Sivas & Barçın & Tam & $\begin{array}{l}\text { TKGM.KK. Td. } \\
\text { 14, s. 37b. }\end{array}$ \\
\hline Sivas/Sivas & Sivas & Çöplü & $1 / 2$ & $\begin{array}{l}\text { TKGM.KK. Td. } \\
14 \text {, s. } 48 \mathrm{~b} .\end{array}$ \\
\hline Sivas/Sivas & Sivas & Estik/Eslim & Tam & $\begin{array}{l}\text { TKGM.KK. Td. } \\
\text { 14, s. } 45 \text { a. }\end{array}$ \\
\hline Sivas/Sivas & Sivas & Karaöyük & Tam & $\begin{array}{l}\text { TKGM.KK. Td. } \\
\text { 14, s. 36b. }\end{array}$ \\
\hline Sivas/Sonisa & Taşabad & Bidevi & Tam & $\begin{array}{l}\text { TKGM.KK. Td. } \\
\text { 12/178, s. 13a. }\end{array}$ \\
\hline Sivas/Sonisa & Taşabad & Hazım & Tam & $\begin{array}{l}\text { TKGM.KK. Td. } \\
\text { 12/178, s. 46b. }\end{array}$ \\
\hline Sivas/Sonisa & Sonisa & Zikdi & $3 / 4$ & $\begin{array}{l}\text { TKGM.KK. Td. } \\
\text { 12, s. 11a. }\end{array}$ \\
\hline Sivas/Sonisa & Sonisa & Zipare & Tam & $\begin{array}{l}\text { TKGM.KK. Td. } \\
\text { 12, s. 33b. }\end{array}$ \\
\hline
\end{tabular}

5- 17. Yüzyıl Sonrasında Abdülvehhab Oğullarının Mülkleri ve Evlatlık Vakfının Durumu

Yaptığımız arşiv çalışmalarında 17. yüzyıl sonrasında Abdülvehhab evladı mülkleri hakkında herhangi bir belgeye ulaşılamamıştır. Arşivlerde sadece

Gaziosmanpasa University Social Sciences Researches Journal 


\section{Rum Eyaleti Evlatlık Vakıflarından Bir Örnek: Abdülvehhab Oğulları Evlatlık Vakfı}

Abdülvehhab evlatlık vakfının Turhal kazasına tabi Boğabağı köyü malikânesinin paylaşımında yaşanan sorunlara dair belgeler tespit edilmiştir. Bu belgeler 18. yüzyılın ikinci yarısı ve 19. yüzyılın ilk yarısına ait kayıtlardır. Evasıt-1 Şevval 1178/02-12 Nisan 1765 tarihli olan ilk belgede, Turhal kazasına tabi Çivril köyü yakınlarında bulunan Boğabağı köyündeki Abdülvehhab tekkesi vakfının mütevellileri Seyyid Bekir, Seyyid Halil ve Seyyid Mustafa'nın Çivril ve Boğabağı köylerinde vakfa ait iki tarla, dört bağ ve bir değirmen ile yine Turhal'a tabi Kurtil köyünde 3 adet arazi gelirine Cafer isimli şahsın haksız olarak müdahale etmesi üzerine yerel mahkemenin kendileri lehine karar verdiği ancak adı geçen şahsın müdahalesini sürdürdüğü ifade edilerek müdahalenin kaldırılması için emr-i ali talep ettiği bildirilmiştir26.

İkinci belge Evahir-i Rebiülevvel 1188/31 Mayss-10 Haziran 1774 tarihli bir fermandır ${ }^{27}$. Fermana göre, Sivas sancağında Turhal nahiyesine tabi Boğabağı köyü malikânesi Abdülvehhab evladı vakfı ve divânisi müteveffa vezir-i azam Mehmed Paşa'nın Turhal'da yaptığı han ve çeşmelerinin suyolları vakfı olup Abdülvehhab evladından Seyyid Hasan, Seyyid Mehmed, Seyyid Mustafa ve Seyyid Ömer adı geçen köyün malikânesini zorla zapt eden Turhal sakinlerinden Müfti Mehmed Efendi, Molla Ahmed ve Şerif Efendilerden alınmasını Divân-1 Hümâyun'dan talep etmişlerdir. Divanda deftere bakıldığında Boğabağı köyü malikânesinin Abdülvehhab evladı vakfına, divanisinin 1070/1660 senesinde vezir-i azam Mehmed Paşa'nın Turhal'da bina eylediği han ve çeşmeleri suyollarına vakfına tahsis edildiği görülmüştür. Bu kayda istinaden 1182/1768 senesinde sadır olan ferman ve kadı müraselesi ile Abdülvehhab evlatları Mehmed, Mustafa ve Ömer Boğabağı malikânesi mahsullünü talep ettiklerinde Şeyh-zâde Abdülmecid'in elindeki askerî beratı ibraz ile malikâne mahsulünü zorla zapt ettiği tekrar divana bildirilmiştir. Divân'da yapılan incelemede Boğabağı ve Bulaş köyleri malikânesinin vaiz İbrahim mahlûlünden adı geçen Şeyhzâde Abdülmecid'e Cemaziyülahır 1180/Kasım 1766 tarihli askerî beratla verildiği tespit edilmiştir. Divan'dan Defter-i Hakanideki kayda itibar edilerek Boğabağ1 malikânesinin Abdülvehhab evladı vakfına olması yönünde Evahir-i Zilhicce 1183/1625 Nisan 1770 tarihli emr-i ali gönderilmiş ancak adı geçen Şeyh-zâde Abdülmecid bunu tanımadığından Abdülvehhab oğulları tekrar Divân'a müracaat etmişlerdir.

\footnotetext{
26 BOA. SAD 10, 319/4.

27 Turhal İlçesi Çivril köyü sakini Fatih Bolat elinde bulunan tecdid-i berat ferman nüshası.
}

| Gaziosmanpaşa Üniversitesi Sosyal Bilimler Araştırmaları Dergisi 


\section{Ali AÇIKEL}

Divân'dan Şeyh-zâde Abdülmecid'i ihtar ve müdahalesinin engellenmesi için Evasit-1 Rebiyülahir 1186/ 12-22 Temmuz 1772 tarihli yeni bir emr-i ali daha gönderilmiştir. Ocak 1774'de Sultan I. Abdülmecid'in tahta çıkmasıyla bu emrin tecdidi talebi üzerine Evâhir-i Rebiyülevvel 1188/31 Mayıs-10 Haziran 1774 tarihli bu fermanın yazıldı̆̆ı belirtilmektedir.

Üçüncü belge, 1574 yılı mufassal tapu defterine ilave edilen 24 Şaban 1192/17 Eylül 1778 tarihli tevki tashih kaydıdır ${ }^{28}$. Bu kayda göre, Turhal kasabasında bulunan Cami-i Kebir' de vâiz olan Şeyh Abdülmecid'in Divân-1 Hümâyun'a gönderdiği arzında Sivas sancağında Turhal nahiyesine tabi Boğabağı köyü malikânesinin Defter-i Hakanide Abdülvehhab evladı vakfına kayıtlı olup nesli münkariz olmasıyla uzun süreden beri Cami-i Kebirde vaiz olanlara tahsis edildiğini ancak Seyyid Ömer ve kardeşlerinin 1182/1768 yılından beri tezviratla Abdülvehhab evladı oldukları iddiasıyla bu malikâneyi talep etmelerinden şikâyetçi olmuştur. Davaları Rumeli kadıaskeri huzurunda görüldüğünde Seyyid Ömer ve kardeşlerinin ellerinde senetleri bulunmaması üzerine iddiaları geçersiz olduğundan Şeyh Abdülmecid lehine emr-i ali verilerek Anadolu muhasebesine işlenmiştir. Bunun üzerine Seyyid Ömer ve kardeşleri ihbar hüccetleri ve Defterhane derkenarıyla yeniden emr-i şerif 1sdar ettirerek vaiz Şeyh Abdülmecid'i mağdur etmişlerdir. Şeyh Abdülmecid, Abdülvehhab evladının münkariz olduğunun kayıtlarda yer aldığını ve adı geçen malikânenin Cami-i Kebir'de vaiz olanlara tahsis edildiğini belirterek yeniden Divan'a müracaat etmiştir. Rumeli kadıaskeri ilamı ve Şeyhülislamın işareti ile Boğabağı köyü malikânesinin Cami-i Kebirde vaiz olarak görev yapan Şeyh Abdülmecid'e tekrar tevcih edilerek Defterhane kaydının tashihi için tevki vezir Es-Seyyid Mustafa'ya emr-i ali yazılmış ve bu tashih kaydı mufassal deftere ilave edilmiştir ${ }^{29}$. Böylece, bu tashih kaydryla Abdülvehhab soyundan gelenlerin münkariz olduğu kesinleşmiştir.

Diğer belgeler, Boğabağı köyü malikânesini tasarruf eden Turhal'daki Cami-i Kebir vaizlerinin tevcih kayıtlarıdır. Örneğin, 6 Şevval 1206/28 Mayıs 1792 tarihli bir hükümde Boğabağı ve Çivril köyleri malikânesi ile Dağharmanı mezrası malikânesini

\footnotetext{
28 TKGM. KK. TD 12, v. 101.

${ }^{29}$ Bu tashih kaydının Sivas Ahkam Defterinde Evasıt-1 Şevval 1192/01-11 Kasım 1778 tarihli bir hükmü de mevcuttur (bkz. BOA. SAD 14, 12/2).
} 


\section{Rum Eyaleti Evlatlık Vakıflarından Bir Örnek: Abdülvehhab Oğulları Evlatlık Vakfı}

tasarruf ederek Cami-i Kebir'de vaiz olan Şeyh Abdülmecid Efendi'nin ölümü üzerine boş kalan vazifesinin oğulları Şeyh Osman ve Şeyh Mustafa'ya tevcih edildiği görülmektedir ${ }^{30}$. Gurre-i Muharrem 1255/17 Mart 1839 tarihli bir diğer belge ise, Boğabağı ve Ulaş köyleri malikâne geliri ile Turhal'da Cami-i Kebirde vaiz olarak görev yapan Es-Seyyid Mehmed Efendi'nin ölümü üzerine boş kalan vazifesinin Hüseyin Efendi' ye tevcihi ile alakalıdır ${ }^{31}$.

\section{Sonuç ve Değerlendirme}

Rum eyaleti evlatlık vakıflarının en önemlilerinden birisi olan Abdülvehhab evlatlık vakfı ve malikâne mülkleri ile alakalı bu çalışmadan bazı genel sonuçlara ulaşmak mümkündür.

İlk olarak, mevcut kaynakların yetersizliğinden Abdülvehhab'ın kimliği hakkında kesin bilgilere ulaşılamamıştır. Değerlendirmelerimize göre, Abdülvehhab Bey'in Osmanlı öncesi dönemde Kadı Burhaneddin Devleti zamanında yaşamış varlıklı yerel beylerden olması muhtemel görünmektedir. Oğulları Osmanlı Devleti'nin Rum eyaletinin muhtelif yerlerinde babalarından kalan malikâne mülkleri tasarruf etmişlerdir. Bu mülklerin önemli bir kısmı ise evlatlık vakıf şeklinde tasarruf edilmiştir.

İkinci olarak, vakfiyesine ulaşılamadığından Abdülvehhab evlatlık vakfının ne zaman tesis edildiği bilinmemektedir. Bu vakfa ait ilk veriler 1455 y1lı tapu tahrir defterinde yer almaktadır. 15 ve 16. yüzyıl tapu tahrir defterlerinden vakfın akarları tam olarak takip edilebilmektedir. Bu defterlerdeki kayıtlara göre, Rum eyaletinin Çorum, Sivas, Tokat, Sonisa ve Niksar kazalarında yaklaşık 23 yerleşim biriminin malikâne gelirleri Abdülvehhab evlatlık vakfınca tasarruf edilmiştir. Bu vakfın yıllık geliri ise 15.000 akçeyi bulmaktadır. Belge yetersizliğinden vakfın 17 ve 18 . yüzyıllardaki akarları hakkında bilgi sahibi olunamamaktadır. 18. asrın son çeyreğine ait belgelerden Abdülvehhab evlatlık vakfının akarı olan Turhal kazasına tabi Boğabağı köyü malikânesinin vakıf evladının münkariz olması sebebiyle Turhal'da Cami-i Kebir vaizlerine tahsis edildiği anlaşılmaktadır.

Son olarak, arşiv kayıtlarından Abdülvehhab'ın bazı malikâne mülklerini

30 VGMA M. 266, 59/3.

| Gaziosmanpaşa Üniversitesi Sosyal Bilimler Araştırmaları Dergisi 


\section{Ali AÇIKEL}

evlatlık vakfına katmadığı görülmektedir. Bunların Rum eyaleti içinde Sonisa ve Sivas kazalarına tabi toplam sekiz yerleşim yerinde bulundukları tespit edilmiştir. 1530' da bu malikâne mülklerin yıllık geliri 8.000 akçeyi bulmaktadır. Malikâne mülk geliri, evlatlık vakıf geliri (1500 akçe) ile birlikte 23.000 akçeye ulaşmaktadır. Bu toplam gelirin yerel ölçekte önemli olduğu değerlendirilebilir.

KAYNAKÇA

a-) Arşiv Kayıtları

Başbakanlık Osmanlı Arşivi (BOA)

BOA. Td. 1083; BOA. Td. 2; BOA. Td. 15; BOA. Td. 19; BOA. Td. 54; BOA. Td. 79; BOA. Td. 387; BOA. SAD 10, 319/4; BOA. SAD 14, 12/2; BOA. Cevdet Maarif 4771.

MC. 081

İstanbul Belediyesi Atatürk Kitaplığı Muallim Cevdet Tasnifi

Tapu ve Kadastro Genel Müdürlüğü Kuyud-1 Kadime Arşivi (TKGM. KK)

TKGM. KK. Td. 10; TKGM. KK. Td. 12; TKGM. KK. Td 14; TKGM. KK. Td. 583

Vakıflar Genel Müdürlüğü Arşivi(VGMA)

VGMA M. 266, 59/3.

Turhal İlçesi Çivril köyü sakini Fatih Bolat elinde bulunan tecdid-i ferman nüshası.

b-) İnceleme Eserler

Aç1kel, Ali, Changes in Settlement Patterns, Population and Society in North Central Anatolia: A Case Study of the District (Kazâ) of Tokat (1574-1643), Basılmamış Doktora Tezi, Manchester Üniversitesi, Manchester 1999, s. 127-136, 200-203.

Akgündüz, Ahmet İslam Hukukunda ve Osmanlı Tatbikatında Vakıf Müessesesi, Ankara 1996.

Barkan, Ömer Lütfi, “Türk-İslam Hukuku Tatbikatının Osmanlı İmparatorluğu'nda Aldığ1 Şekiller: Mâlikâne-Divânî Sistemi", Türk Hukuk ve İktisat Tarihi Mecmuası, cilt: 2, İstanbul 1939, s. 119-184 (Aynı yayının yeniden basımı için ayrıca bkz. Ömer Lütfi Barkan, Türkiye'de Toprak Meselesi, Toplu Eserler, I, Gözlem Yayınları, İstanbul 1980, s. 151-208).

Barkan, Ömer Lütfi, “Türk-İslam Toprak Hukuku Tatbikatının Osmanlı İmparatorluğu'nda Aldığı Şekiller Şer'i Miras Hukuku ve Evlatlık Vakıflar", Türkiye'de Toprak Meselesi Toplu Eserler 1, İstanbul 1980, s. 212-214.

Beldicaeanu-Steinherr, Irène, "Fiscalité et Formes de Possession de la Terre Arable dans L'Anatolie Préottomane", JESHO (1976), XIX, s. 233-322;

Beldiceanu, N., "Recherches sur la Réforme Foncière de Mehmed II", Acta Historica, IV (1966), s. 27-39.

${ }^{31}$ BOA. Cevdet Maarif 4771.

Gaziosmanpasa University Social Sciences Researches Journal 


\section{Rum Eyaleti Evlatlık Vakıflarından Bir Örnek: Abdülvehhab Oğulları Evlatlık Vakfı}

Berki, Ali Himmet, Vakfa Dair Yazılan Eserlerle Vakfiye ve Benzeri Vesikalarda Geçen Istılah ve Tâbirler, Ankara 1966.

Cvetkova, Bistra, "Sur Certaines Reformes du Régime Foncier au Temps de Mehmed II", JESHO, VI (1963), s.104-120.

Hanilçe, Murat, XV ve XVI. Yüzyılda Zile Kazası (1455-1574), Basılmamış Doktora Tezi, Gaziosmanpaşa Üniversitesi Sosyal Bilimler Enstitüsü, Tokat 2014.

İnalcık, Halil, "Rice Cultivation and the Çeltükçi Re'âyâ System in the Ottoman Empire", AO, VI (1982), 69-141.

İnalc1k, Halil, "The Ottoman State: Economy and Society, 1300-1600", An Economic and Social History of the Ottoman Empire, 1300-1914, eds. Halil İnalc1k and Donald Quataert, Cambridge1994, s.1-410.

Moutafchieva, Vera P., Agrarian Relations in the Ottoman Empire in the 15th and 16th Centuries, New York 1988.

Öz, Mehmet, Population, Taxation and Regional Economy in the District of Canik (According to Ottoman tahrir Defters, 1455-1576), Doktora Tezi, Cambridge Üniversitesi, Cambridge/İngiltere 1990.

Öz, Mehmet, XV-XVI. Yüzyıllarda Canik Sancağı, Türk Tarih Kurumu Yayını, Ankara 1999.

Özel, Oktay, Changes in Settlement Patterns, Population and Society in Rural Anatolia: A Case Study of Amasya (1576-1642), Basılmamış Doktora Tezi, Manchester Üniversitesi, Manchester 1993.

Öztürk, Nazif, Menşe'i ve Tarihi Gelişimi Açısından Vakıflar, Ankara 1983.

Sertoğlu, Mithat, “Osmanlı İmparatorluğu'nda XV. ve XVI. Asırlarda Girişilen Toprak Reformları", Belgelerle Türk Tarihi Dergisi, 35 (1970), s. 68-71.

Sertoğlu, Midhat, Osmanlı Tarih Lügati, İstanbul 1986.

Şemseddin Sami, Kâmûs-ı Türkî, Dersa'adet 1317.

Turan, Osman, Selçuklular ve İslamiyet, İstanbul 1971.

Venzke, Margaret L., “Aleppo's Mâlikâne-Divânî System”, Journal of American Oriental Society, 106 (1986), s. 451-469.

Yediyıldız, Bahaeddin, "Vakıf", İA, C. 13, İstanbul 1986.

Yediyıldız, Bahaeddin, Ordu Kazası Sosyal Tarihi, Kültür ve Turizm Bakanlı̆̆ı Yayınları, Ankara 1985.

Yediyıldız, Bahaeddin, XVIII. Yüzyılda Türkiye'de Vakıf Müessesesi Bir Sosyal Tarih İncelemesi, Ankara 2003.

| Gaziosmanpaşa Üniversitesi Sosyal Bilimler Araştırmaları Dergisi 
